\title{
SOBRE A LEGITIMIDADE DEMOCRÁTICA DA INTERVENÇÃO JU- DICIAL NO PROCESSO LEGISLATIVO: UMA CRÍTICA AO CON- TROLE PREVENTIVO DE CONSTITUCIONALIDADE PELO STF
}

\author{
ON THE DEMOCRATIC LEGITIMITY OF LEGAL INTERVENTION \\ IN THE LEGISLATIVE PROCESS: A CRITICISM TO THE PREVENTIVE \\ JUDICIAL REVIEW BY THE STF
}

\author{
Cláudio Ladeira de Oliveira ${ }^{1}$ \\ Luiz Eduardo Lapolli Conti ${ }^{2}$ \\ Isaac Kofi Medeiros ${ }^{3}$
}

\begin{abstract}
RESUMO: Este artigo pretende discutir a legitimidade democrática do controle preventivo de constitucionalidade do processo legislativo, tal como vem sendo praticado pela jurisprudência do Supremo Tribunal Federal no Brasil. Inicialmente apresentamos o debate entre Ronald Dworkin e Jeremy Waldron para ilustrar alguns dos problemas relativos à legitimidade do controle judicial de constitucionalidade. Em seguida analisamos a construção do controle judicial preventivo de constitucionalidade no Brasil pelo Supremo Tribunal Federal, destacando casos recentes em que o Tribunal, monocraticamente, interferiu no processo legislativo por discordância com o conteúdo das deliberações parlamentares. Por fim, apresentamos uma crítica à legitimidade da intervenção judicial no processo legislativo.
\end{abstract}

Palavras-Chave: Democracia; controle preventivo de constitucionalidade; ativismo judicial; representação política; processo legislativo.

\footnotetext{
${ }^{1}$ Doutor em Direito pela Universidade Federal de Santa Catarina (UFSC). Professor adjunto da Faculdade de Direito da Universidade Federal de Santa Catarina (UFSC). Coordenador do Grupo de Pesquisa em Constitucionalismo Político da UFSC - GConst. Contato: claudioladeira@hotmail.com. ORCID: https://orcid.org/0000-0002-8936-9474.

${ }^{2}$ Doutorando em Direito no Programa de Pós-Graduação em Direito da Universidade Federal de Santa Catarina (PPGD/UFSC). Professor do Curso de Direito das Faculdades ESUCRI. Membro do Grupo de Pesquisa em Constitucionalismo Político da UFSC - GConst. Contato: luiz_conti1@yahoo.com.br. ORCID: https://orcid.org/0000-0001-7405-6582.

${ }^{3}$ Mestrando em Direito, Estado e Sociedade pelo Programa de Pós-Graduação em Direito da Universidade Federal de Santa Catarina, dentro da linha de pesquisa Constitucionalismo, Democracia e Organização do Estado. Graduado em Direito pela UFSC. Membro do Grupo de Pesquisa em Constitucionalismo Político da UFSC GConst. Membro da Comissão de Direito Constitucional da OAB/SC. Advogado atuante na área de Direito Público. Contato: isaackofimedeiros@gmail.com. ORCID: https://orcid.org/0000-0003-0246-512X.
} 


\begin{abstract}
This article aims to discuss the democratic legitimacy of the preventive judicial review of the legislative process, as practiced by the jurisprudence of the Supreme Court in Brazil. We initially present the debate between Ronald Dworkin and Jeremy Waldron to illustrate some of the problems regarding the legitimacy of judicial review. Then we analyze the construction of the preventive judicial control of constitutionality in Brazil by the Federal Supreme Court, highlighting recent cases in which the Court, monocratically, interfered in the legislative process by disagreement with the content of parliamentary deliberations. Finally, we criticize the legitimacy of judicial intervention in the legislative process.
\end{abstract}

Keywords: Democracy; preventive judicial review; judicial activism; legislative process; political representation.

Sumário: 1. Introdução; 2. O debate Dworkin versus Waldron sobre a legitimidade democrática do controle de constitucionalidade; 3 . A construção do controle preventivo judicial de constitucionalidade na jurisprudência do Supremo Tribunal Federal; 4. Dois exemplos da atuação do Supremo no controle preventivo de constitucionalidade; 5. Judicialização da política, ativismo judicial e legitimidade democrática; 6. Considerações Finais; 7. Referências bibliográficas.

\title{
1. INTRODUÇÃO
}

O objetivo do artigo é questionarmos, a partir de argumentos normativos ${ }^{4}$, a legitimidade democrática das intervenções do Supremo Tribunal Federal no processo legislativo, por meio do controle judicial preventivo de constitucionalidade. Mesmo diante da centralidade que a Constituição lega ao Poder Judiciário na tutela dos direitos fundamentais e da resolução das controvérsias políticas, não se pode olvidar o papel dos demais poderes na definição da agenda política nacional. A judicialização excessiva do processo político, entretanto, gerou um desgaste dos poderes democráticos, favorecendo o protagonismo dos Tribunais.

Uma das formas mais abrangentes de influência ou interferência sobre a pauta política por parte do Supremo Tribunal Federal está baseada na possibilidade do tribunal em exercer o controle de constitucionalidade preventivo sobre o processo legislativo. Pensado inicialmente como exceção, essa forma de revisão judicial tem demonstrado o papel cada vez mais ativista

\footnotetext{
${ }^{4}$ Segundo Oliveira (2015, p. 189), "análises 'normativas' justificam a adoção de arranjos institucionais argumentando em defesa de sua legitimidade política. [...] Por sua vez, uma perspectiva 'descritiva' analisa explica as ações de indivíduos e grupos, descritos como agentes buscam promover seus interesses e valores apoiados em crenças (sobre as consequências prováveis de suas ações e os comportamentos dos demais indivíduos e grupos), limitados/autorizados por determinadas instituições, as quais ampliam ou restringem suas oportunidades de ação".
} 
do Judiciário brasileiro, pronto a impor suas pautas (geralmente pautas individuais dos Ministros) ao conjunto da sociedade.

Para alcançar os resultados pretendidos, o artigo foi divido em quatro partes. Inicialmente, pretendemos apresentar o debate entre Ronald Dworkin e Jeremy Waldron para ilustrar alguns dos problemas relativos à legitimidade do controle judicial de constitucionalidade. Na perspectiva de Dworkin, a atuação dos tribunais no exercício do judicial review se justifica por conta de um modelo substancial de democracia, que exige uma postura ativista na concretização dos valores constitucionais. Waldron, por outro lado, refuta o judicial review por entender que ele é incompatível com uma sociedade democrática, que pressupõe que os desacordos morais sejam resolvidos por decisões dos próprios cidadãos e não por magistrados que não são eleitos.

Em um segundo momento, analisaremos a construção do controle judicial preventivo de constitucionalidade no Brasil. Criado na jurisprudência do Supremo Tribunal Federal ainda na vigência da Constituição de 1967/69, tal instrumento tinha por objetivo proteger o núcleo essencial da Constituição, as chamadas cláusulas pétreas. Sua utilização no Tribunal, entretanto, era bastante prudente, o que, inclusive, suscitava críticas relevantes da doutrina.

A seguir, estudaremos dois casos recentes em que o Tribunal, monocraticamente, interferiu no processo legislativo por discordância com o conteúdo das deliberações parlamentares. Além de analisar os argumentos jurídicos expostos pelos magistrados nos julgamentos dos mandados de segurança $\mathrm{n}^{\circ} 32.033$ e $\mathrm{n}^{\mathrm{o}} 34.530$, trataremos de apresentar a repercussão política e social dessas decisões.

Por fim, no último tópico, vamos ilustrar o processo de crescente judicialização da vida política e social brasileira e demonstrar a postura ativista adotada pelo Judiciário nos últimos anos com o intuito de questionar a legitimidade da intervenção judicial no processo legislativo. Enquanto a judicialização pode ser identificado como um fenômeno contingencial das escolhas do constituinte, o ativismo decorre de uma atitude voluntária do magistrado, o que cria um significativo déficit democrático.

\section{O DEBATE DWORKIN versus WALDRON SOBRE A LEGITIMIDADE DEMO- CRÁTICA DO CONTROLE DE CONSTITUCIONALIDADE}


Umas das justificativas teóricas mais consistentes e influentes para o controle de judicial constitucionalidade apoiado na interpretação de princípios abstratos é geral é aquela oferecida por Ronald Dworkin (OLIVEIRA, 2008, p. 5). Para o jurista norte-americano, os juízes não só possuem legitimidade para anular decisões do Legislativo como, ao fazê-lo, aprimoram a democracia (MENDES, 2008, p. 33). Ou seja, não existe uma tensão evidente entre democracia e revisão judicial, mas complementariedade.

Segundo Dworkin (2006, p. 31), existem duas concepções de democracia: a democracia majoritária e a constitucional. A primeira se baseia na premissa majoritária, ou seja, na ideia de que "todas as decisões de princípios devem ser decididas pelo voto da maioria" (DWORKIN, 2010a, p. 189). Neste caso, a democracia "repousa na compatibilidade entre a decisão política e a vontade da maioria" (DWORKIN, 2005a, p. 502).

Obviamente, a partir dessa concepção majoritarista, qualquer espécie de revisão judicial, ou seja, o desenho institucional em que "juízes nomeados têm o poder de declarar nulas as leis aprovadas pelo poder legislativo e outras instituições representativas" (DWORKIN, 2010a, p. 360), não pode ser considerada outra coisa senão antidemocrática (DWORKIN, 2010a, p. 190).

Mas é possível pensar em uma forma alternativa de democracia, a constitucional ou coparticipativa, que exige o preenchimento de determinadas condições de igualdade dos membros de uma comunidade. Como afirma o jurista, "a melhor estrutura institucional é aquela que produz as melhores respostas para a pergunta (de caráter essencialmente moral) de quais são efetivamente as condições democráticas e que melhor garante uma obediência estável a essas condições" (DWORKIN, 2006, p. 52).

Para Dworkin (2003, p. 172), “uma das precondições da democracia legitima encontra-se na exigência de que o governo trate todos os cidadãos como iguais e respeite suas liberdades fundamentais e sua dignidade". Assim, conforme o autor:

\footnotetext{
O objetivo que define a democracia tem que ser diferente [da premissa majoritária]: que as decisões coletivas sejam tomadas por instituições políticas cuja estrutura, composição e modo de operação dediquem a todos os membros da comunidade, enquanto indivíduos, a mesma consideração e respeito. É certo que essa explicação alternativa de objetivo da democracia exige uma estrutura de Estado muito semelhante à exigida pela premissa majoritária. [...] Porém, a concepção constitucional requer esses procedimentos majoritários em virtude de uma preocupação com a igualdade dos cidadãos, e não por causa de um compromisso com as metas da soberania da maioria (DWORKIN, 2006, p. 26).
} 
Este modelo de democracia, portanto, não pode ser incompatível com procedimentos contra majoritários ocasionais, que tenha por objetivo "proteger ou promover a igualdade que, segundo essa concepção, é a própria essência da democracia” (DWORKIN, 2006, p. 26). Afinal, "a regra da maioria não é nem mesmo legítima, muito menos democrática, a menos que essas condições sejam ao menos substancialmente atendidas" (DWOKIN, 2010a, p. 191).

É razoável, portanto, que "uma classe pequena e especial de decisões políticas" deva ser tomada por juízes não eleitos (DWORKIN, 2005, p. 30). Os juízes, justamente por estarem alheios ao processo majoritário, estão em uma posição mais adequada para tomar decisões em favor das minorias do que o Legislativo:

\begin{abstract}
Os legisladores que foram eleitos, e precisam ser reeleitos, por uma maioria política tendem mais a tomar o partido de tal maioria em qualquer discussão séria sobre os direitos de uma minoria contrária; se se opuserem com excessiva firmeza aos desejos da maioria, esta irá substituí-los por aqueles que não se opõem. Por esse motivo, os legisladores parecem menos inclinados a tomar decisões bem fundadas sobre os direitos das minorias do que as autoridades que são menos vulneráveis nesse sentido (DWORKIN, 1999, pp. 448-449).
\end{abstract}

Mesmo quando o debate legislativo é qualificado, "o processo majoritário estimula soluções de meio-termo que põem em segundo plano importantes questões de princípios" (DWORKIN, 2006, p. 47). Ao legar aos tribunais um papel relevante na proteção dos direitos fundamentais, Dworkin (2005, p. 32) entende que "as minorias ganham poder político", preservando o desenho de equidade pretendido na democracia constitucional.

Mas é preciso determinar com clareza quais são as decisões políticas que devem ser protegidas da deliberação da maioria. Dworkin (2010, p. 129) distingue dois tipos de argumentos que justificam as decisões políticas: (1) argumentos de política (policy) e (2) argumentos de princípio $^{5}$. Essa diferenciação estabelece os limites entre as funções do juiz e do legislador, distribuindo a "responsabilidade política entre os dois de maneira diferente" (MENDES, 2008, p. 37).

Segundo Dworkin (2010, p. 129), os argumentos de política justificam a decisão “mostrando que a decisão fomenta ou protege algum objetivo coletivo da comunidade como um

\footnotetext{
${ }^{5} \mathrm{Na}$ obra Uma questão de princípio, Dworkin denomina esses dois argumentos de forma ligeiramente diferente: argumentos de princípio político e argumentos de procedimento político (DWORKIN, 2005, p. 6).
} 
todo". Por sua vez, os argumentos de princípio justificam uma decisão "mostrando que a deci-

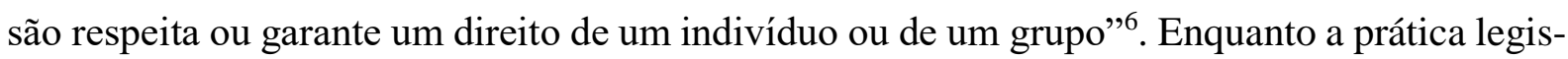
lativa pode exigir as duas espécies de argumento, os tribunais só podem decidir por argumentos de princípios (DWORKIN, 2005, p. 101; DWORKIN, 2010, p. 132).

Nessa visão, os direitos são "trunfos" contra metas coletivas, contra decisões da maioria, mesmo que elas "tenham sido alcançadas mediante os mecanismos normais das instituições que não são questionadas" (DWORKIN, 2005, p. 296). Os direitos só são direitos caso tenham "um certo peso contra as metas coletivas em geral” (DWORKIN, 2010, p. 144). É a partir dessa perspectiva, a do direito como trunfos, que Dworkin defende o ativismo judicial.

Para o jurista norte-americano, o "ativismo judicial sustenta que os tribunais devem aceitar a orientação das chamadas cláusulas constitucionais vagas" (DWORKIN, 2010, p. 215). Essas cláusulas "pressupõe que os cidadãos têm certos direitos morais contra o Estado", de modo que o "ativismo somente pode ser justificado como um programa baseado em algo mais que preferências pessoais dos juízes"7 (DWORKIN, 2010, pp. 216-7). Deste modo, o autor defende que:

\begin{abstract}
As cláusulas difíceis [...] devem ser entendidas como um apelo a conceitos morais, e não como uma formulação de concepções específicas. Portanto, um tribunal que assume o ônus de aplicar plenamente tais cláusulas como lei deve ser um tribunal ativista, no sentido de que ele deve estar preparado para formular questões de moralidade política e dar-lhes uma resposta" (DWORKIN, 2010, p. 231).
\end{abstract}

O controle de constitucionalidade, portanto, "assegura que as questões mais fundamentais de moralidade política serão finalmente expostas e debatidas como questões de princípio e não apenas de poder político" (DWORKIN, 2005, p. 102). Ele, inclusive, pode contribuir para o debate político, ao obrigar aos órgãos representativos a incorporar elementos de princípios jurídicos bem antes de eles serem levados aos tribunais.

\footnotetext{
${ }^{6}$ Antes de apresentar a distinção entre argumentos de política e de princípio, Dworkin (2010, p. 36) já diferenciava política de princípio nos seguintes termos: "Denomino 'política' aquele tipo de padrão que estabelece um objetivo a ser alcançado, em geral uma melhoria de algum aspecto econômico, político ou social da comunidade [...]. Denomino 'princípio' um padrão que deve ser observado, não porque vá promover ou assegurar uma situação econômica, política ou social considerada desejável, mas porque é uma exigência de justiça ou equidade ou alguma outra dimensão da moralidade".

${ }^{7}$ Dworkin vai exigir um padrão de integridade constitucional: para ele, a leitura moral não implica que os "juízes podem dizer que a Constituição expressa suas próprias conviç̧ões", mas que ela é produto de um trabalho de equipe entre "os demais funcionários da justiça do passado e do presente, que elaboram juntos uma moralidade constitucional coerente".
} 
No polo oposto da defesa do controle de constitucionalidade de Dworkin, encontramos Jeremy Waldron. Para Waldron (2003, p. 01), “a legislação e as legislaturas têm má fama na filosofia jurídica e política, uma fama suficiente má para lançar dúvidas quanto a suas credenciais como fontes de direito respeitáveis". Seu objetivo, portanto, é recuperar a dignidade da legislatura, enquanto fonte respeitável de direito (WALDRON, 2003, p. 03).

O dado essencial para Waldron (1999, p. 01) é o fato de que "há muitos de nós, e discordamos sobre a justiça". Esse desacordo, longe de ser uma patologia, constitui uma "característica persistente da política contemporânea"8 (MENDES, 2008, p. 81). A existência desse desacordo é, em última análise, o que justifica a construção de instituições políticas.

Como não poderia ser diferente, o desacordo atinge inclusive as concepções individuais sobre quais são os direitos que as pessoas devem ter, qual seu conteúdo e limites para seu exercício. Existe, portanto, a necessidade de se instituir um método para produzir normas jurídicas e impor uma solução única para todos (WALDRON, 2003, p. 44).

Waldron $(1999$, p. 03) pondera que existem, ao menos, duas tarefas para a filosofia política: refletir sobre a justiça ou refletir sobre política. Sem querer colocar em descrédito a primeira tarefa, o jurista neozelandês defende uma pauta focada no papel das instituições políticas, e de como elas podem contribuir para a resolução do desacordo sobre direitos ${ }^{9}$.

Deste modo, nenhuma teoria do direito pode prescindir de uma teoria da autoridade:

Entretanto, dada a inevitabilidade do desacordo sobre tudo isso, uma teoria da justiça e dos direitos deve ser complementada com uma teoria da autoridade. Uma vez que as pessoas discordam sobre quais são o que justiça exige e quais direitos possuímos, devemos perguntar: quem tem o poder de tomar decisões, ou por meio de que processos as decisões devem ser tomadas, sobre as questões práticas que as teorias concorrentes da justiça e dos direitos pretendem abordar? (WALDRON, 1993, p. 32)

\footnotetext{
${ }^{8}$ Segundo Rawls (2000, p. 24), “uma sociedade moderna não se caracteriza apenas por um pluralismo de doutrinas religiosas, filosóficas e morais abrangentes. Nenhuma dessas doutrinas é professada pelos cidadãos em geral. Nem se deve esperar que, num futuro previsível, uma ou outra doutrina razoável chegue a ser professada algum dia por todos os cidadãos, ou por quase todos. O liberalismo político pressupõe que, para propósitos políticos, uma pluralidade de doutrinas abrangentes e razoáveis, e, ainda assim, incompatíveis, seja o resultado normal do exercício da razão humana dentro da estrutura das instituições livres de um regime democrático constitucional".

${ }^{9}$ É importante destacar que Waldron se define como um "positivista normativo". Para ele, a separação entre direito e moral, uma das teses essenciais para o positivismo em autores como Kelsen e Hart, justifica-se não apenas no plano teórico, mas também normativo: “[...] a separação entre o direito e moralidade, ou essa separação entre o julgamento jurídico e o julgamento moral, é uma coisa boa, talvez indispensável (do ponto de vista moral, social ou político) e certamente é algo que deve ser valorizado e encorajado" (WALDRON, 2001, p. 411).
} 
A partir daí Waldron coloca em destaque o papel do processo político e, especialmente, a legislatura como espaço privilegiado para a resolução das controvérsias sobre justiça. Ao mesmo tempo, como decorrência lógica, o jurista refuta as justificativas tradicionais do controle de constitucionalidade.

Na realidade, para Waldron (2003, p. 05), a indignidade com que a legislação é vista atualmente decorre da valorização do judicial review como "palavra final em questões de direito e de princípio". Esse "desconforto com a democracia" faz com que a legislação seja tratada de forma subsidiária, "tolerada apenas quando nenhum dos modos mais refinados de resolução jurídica se aplicam” (WALDRON, 1999, p. 08).

Uma das razões que pode explicar esse fenômeno é uma suposta irracionalidade decorrente do modo como as leis adquirem autoridade jurídica. Ao contrário das decisões judiciais, que se assentam na razão, as leis "impõem-se como autoridade com nada mais crível do que os números a seu lado" (WALDRON, 2003, p. 154). Haveria, portanto, uma arbitrariedade na regra da maioria, o que geraria riscos para os direitos individuas da minoria (WALDRON, 2003, p. 155).

Entretanto, a regra da maioria é inerente a qualquer processo decisório, inclusive no âmbito do Judiciário. Frequentemente os membros de um determinado tribunal divergem sobre determinada questão de direito e se utilizam da votação como método de decisão. "A diferença, quando uma questão é deslocada da legislatura para o tribunal, é [...] de grupos constituintes, não [...] de métodos de decisão" (WALDRON, 2003, p. 156).

A questão subjacente, portanto, não é a regra da maioria, mas quem está mais apto a decidir sobre as "questões para as quais o consentimento [da comunidade] é relevante" (WALDRON, 2003, p. 178). O processo legislativo seria mais legitimo para a tomada dessa espécie de decisão porque reclama autoridade sem ocultar os conflitos que circundam sua produção (MENDES, 2008, p. 87).

Justamente aí, na possibilidade de tomar decisões sem olvidar do dissenso, é que Waldron vai encontrar a dignidade da legislação. A legislação “é, em parte, o tributo que devemos pagar à conquista da ação concertada, cooperativa, coordenada ou coletiva nas circunstâncias da vida 
moderna"10 (WALDRON, 2003, p. 190). O único método que efetivamente respeita o pluralismo político é o processo legislativo conduzido com base no princípio majoritário (MELLO, 2010, p. 37). Para Waldron (2003, pp. 192-3):

\begin{abstract}
A decisão majoritária não é apenas um processo decisório eficaz, é um processo respeitoso. Respeita os indivíduos de duas maneiras. Primeiro, respeita e considera seriamente a realidade das duas diferenças de opinião quanto à justiça e ao bem comum. A decisão majoritária não requer que a opinião de ninguém seja menosprezada ou silenciada por causa da importância imaginada do consenso. Ao impor o nosso apoio e o nosso respeito como processo decisório, ele não exige que nenhum de nós finja haver um consenso quando não há, meramente porque pensamos que deveria haver quer porque qualquer consenso é melhor do que nenhum, quer porque a visão evidentemente correta por si que não conseguimos imaginar como alguém poderia sustentar o contrário.
\end{abstract}

Nesse contexto, não há espaço para o controle de constitucionalidade de leis pelo Poder Judiciário $^{11}$. Waldron, inclusive, vai se destacar como um dos grandes críticos do judicial review. A teoria jurídica estaria por demais acostumada com uma oposição entre uma imagem idealizada do judiciário e uma "descrição 'crua' da política realmente existente, atenta aos seus aspectos mais negativos de um modo que a descrição do judiciário não faz" (OLIVEIRA, 2008, p. 09).

Waldron (2016, p. 199) distingue duas espécies de controle de constitucionalidade. Em um sistema "forte" de controle de constitucionalidade (strong judicial review), os tribunais têm autoridade para se recusar a aplicar a lei em casos particulares ou modificar a lei para conformála aos direitos individuais. Algumas vezes, por meio de mecanismos de stare decisis ou de preclusão, as cortes têm poder de transformar uma lei em "letra morta" (WALDRON, 2016, p. 200).

Ao contrário, no sistema "fraco" de controle de constitucionalidade (weak judicial review), os tribunais têm autorização para analisar a legislação para verificar sua compatibilidade

\footnotetext{
${ }^{10}$ Não por acaso, Hannah Arendt (2001, p. 258) apontava que a "ação é, de fato, a única faculdade miraculosa que o homem possui". Para a filósofa, um milagre é "aquilo que irrompe no mundo como uma 'improbabilidade infinita" e, a partir daí, desencadeia um processo histórico que só vai ser interrompido por uma nova iniciativa humana, "pelo initium que é o homem enquanto ser que age" (ARENDT, 2002, pp. 218-219).

${ }^{11} \mathrm{Na}$ verdade, mais recentemente Waldron (2018) atenuou em parte suas críticas contra o controle de constitucionalidade, admitindo a possibilidade de um controle forte de constitucionalidade, desde que com algumas alterações como, por exemplo, quóruns diferenciados (ou mesmo a unanimidade) para que as cortes possam declarar a inconstitucionalidade de uma norma, além de uma exigência argumentativa maior dos magistrados quando se trata de "invalidar uma decisão tomada por um dos poderes do governo que é democrático e politicamente responsável”.
} 
com os direitos individuais, mas não pode deixar de aplicá-la simplesmente porque violariam esses direitos (WALDRON, 2016, p. 200). É contra o primeiro desses sistemas que Waldron dirige suas críticas.

Para o jurista, o controle de constitucionalidade não se justifica sempre que uma sociedade apresenta as seguintes características:

(1) instituições democráticas funcionando razoavelmente bem, incluindo uma legislatura representativa eleita com base no sufrágio universal adulto; (2) um conjunto de instituições judiciais, de novo, funcionando razoavelmente bem, configurado em uma base não representativa para julgar ações individuais, resolver disputas e sustentar o Estado de direito; (3) um compromisso da parte da maioria dos membros da sociedade e de seus agentes públicos com a ideia de direitos individuais e da minoria; e (4) um desacordo persistente, substancial, de boa-fé sobre direitos [...] entre os membros da sociedade que estão comprometidos com a ideia de direitos (WALDRON, 2016, p. 203).

Nesse tipo de sociedade, os desacordos sobre direitos devem ser resolvidos usando suas instituições legislativas, de modo que deixar para as cortes essa atribuição gera déficits de legitimidade política (WALDRON, 2016, p. 203). Do mesmo modo, não se sustenta a visão de que as Cortes erram menos do que as legislaturas:

O controle de constitucionalidade baseado em direitos é normalmente defendido apontando-se a probabilidade de que o procedimento democrático da maioria leve a resultados injustos. E assim eles podem. Mas assim pode qualquer procedimento que procura solucionar o problema da escolha social em face do desacordo sobre o que é injustiça ou tirania. A prática americana de permitir que a Suprema Corte dê a última palavra (pelo voto da maioria dos seus membros) em temas de direitos fundamentais já produziu decisões flagrantemente injustas (WALDRON, 1999, p. 247).

E mesmo que os tribunais fossem aptos a fornecer a "resposta certa" sobre as questões políticas fundamentais, essa resposta seria incapaz de superar os desacordos vigentes em uma sociedade pluralista (MENDES, 2011, p. 26). A "Supremacia Judicial”, deste modo, serviria apenas para enfraquecer a participação dos indivíduos. Para a pergunta "quem deve ter o poder de decidir?", Waldron $(1999,244)$ não consegue achar resposta mais legitima do que: “as pessoas cujos os direitos estão em jogo têm o direito de participar em termos igualitários da decisão".

\section{A CONSTRUÇÃO DO CONTROLE PREVENTIVO JUDICIAL DE CONSTITUCI- ONALIDADE NA JURISPRUDÊNCIA DO SUPREMO TRIBUNAL FEDERAL}


Não obstante as críticas de Waldron, é certo que na maior parta das democracias modernas se consagrou, sob o ideal da supremacia da constituição, o controle judicial de constitucionalidade (WALDRON, 2018, p. 11). Inclusive matérias que tradicionalmente eram entendidas como interna corporis do parlamento, como, por exemplo, o processo legislativo ${ }^{12}$, não escapam atualmente do escrutínio judicial.

A admissão do controle judicial preventivo de constitucionalidade no Brasil nasceu a partir de uma construção jurisprudencial do Ministro Moreira Alves, no julgamento do Mandado de Segurança $n^{\circ}$ 20.257, ainda na vigência da Constituição de 1967/69 (MENDES et al, 2010, p. 1240). Tratava-se de ato impetrado pelos Senadores Itamar Franco e Antonio Mendes Canale contra a Mesa do Congresso Nacional para impedir a tramitação de emendas constitucionais que, na sua visão, contrariavam cláusulas pétreas ${ }^{13}$.

Na ocasião, abrindo divergência com o relator, Ministro Décio Miranda, o Ministro Moreira Alves assim se pronunciou:

[...] No $\S 1^{\circ}$ do artigo 47 da Constituição Federal, preceitua-se que: "Não será objeto de deliberação a proposta de emenda tendente a abolir a Federação ou a República". Objeto de deliberação significa, sem a menor dúvida, objeto de votação, porque é neste momento que se delibera a favor da emenda ou contra ela.

Por outro lado, se a direção dos trabalhos do Congresso cabe ao Presidente do Senado; se este, pelo próprio Regimento Comum do Congresso Nacional (artigo 73), pode, liminarmente, rejeitar a proposta de emenda que não atenda ao disposto no art. $47, \S$ $1^{\circ}$, da Constituição (e quem tem poder de rejeição liminar o tem, igualmente, no curso do processo); e se a Constituição alude a objeto de deliberação o que implica dizer que seu termo é o momento imediatamente anterior à votação); não há dúvida, a meu ver, de que, a qualquer tempo, antes da votação, pode a Presidência do Congresso, convencendo-se de que a proposta de emenda tende a abolir a Federação ou a República, rejeitá-la, ainda que não o tenha feito inicialmente.

Cabível, portanto, no momento em que o presente mandado de segurança foi impetrado, sua impetração preventiva, uma vez que visava ele a impedir que a Presidência do Congresso colocasse em votação a proposta de emenda. Aprovada esta, o mandado de segurança - como tem entendido esta Corte - se transforma de preventivo em restaurador da legalidade.

\footnotetext{
${ }^{12}$ Essa era a opinião de Francisco Campos (1956, p. 122), para quem "seria, evidentemente, violar o princípio de separação dos poderes, atribuir ao Judiciário a faculdade de rever o processo de elaboração legislativa, submetendo as decisões da Câmara, nesta matéria, ao seu controle ilimitado, pois que a própria Câmara, tomando as deliberações em questão, já deliberou, naturalmente de maneira irrevogável para ela, sobre a regularidade e observância dos processos e trâmites de formação da lei".

${ }^{13}$ Consta do relatório que os impetrantes "requerem mandado de segurança contra a Mesa do Congresso Nacional, na pessoa de seu Presidente, o Exmo. Sr. Senador Luiz Viana Filho, a fim de que seja impedida da tramitação das Propostas de Emendas Constitucionais $\mathrm{n}^{\text {os }} 51$ e 52/80, bem assim da Emenda $\mathrm{n}^{\mathrm{o}} 3$ às referidas Propostas. Argumentam que ditas Emendas, visando à prorrogação dos mandatos dos atuais Prefeitos, Vice-Prefeitos e Vereadores, não podem ser objeto de deliberação, ante o que dispõe o art. $47, \S 1^{\circ}$, da Constituição, segundo o qual "não será objeto de deliberação a proposta de emenda tendente a abolir a Federação e República".
} 
[...] Não admito mandado de segurança para impedir tramitação de projeto de lei ou proposta de emenda constitucional com base na alegação de que conteúdo entra em choque com algum princípio constitucional. E não admito porque, nesse caso, a violação à Constituição só ocorrerá depois de o projeto se transformar em lei ou de a proposta de emenda vir a ser aprovada. Antes disso, nem o Presidente da Casa do Congresso, ou deste, nem a Mesa, nem o Poder Legislativo estão praticando qualquer inconstitucionalidade, mas estão, sim, exercitando seus poderes constitucionais referentes ao processamento da lei em geral. A inconstitucionalidade, nesse caso, não será quanto ao processo da lei ou da emenda, razão por que só poderá ser atacada depois da existência de uma ou de outra.

Diversa, porém, são as hipóteses como a presente, em que a vedação constitucional se dirige ao próprio processamento da lei ou da emenda, vedando a sua apresentação (como é o caso previsto no parágrafo único do artigo 57) ou a sua deliberação (como na espécie). Aqui, a inconstitucionalidade diz respeito ao próprio andamento do processo legislativo, e isso porque a Constituição não quer - em face da gravidade dessas deliberações, se consumadas - que sequer se chegue à deliberação, proibindo-a taxativamente. A inconstitucionalidade, neste caso, já existe antes de o projeto ou de a proposta se transformarem em lei ou em emenda constitucional, porque o próprio processamento já desrespeita, frontalmente, a Constituição.

E cabe ao Poder Judiciário - nos sistemas em que o controle de constitucionalidade lhe é outorgado - impedir que se desrespeite a Constituição. Na guarda da observância desta, ele está acima dos demais Poderes, não havendo, pois, que falar-se, a esse respeito, em independência de Poderes. Não fora assim e não poderia ele exercer a função que a própria Constituição, para a preservação dela, lhe outorga ${ }^{14}$.

Em razão dessa decisão, firmou-se o entendimento de que membros do Congresso Nacional possuíam legitimidade ativa para provocar o Supremo Tribunal Federal para analisar, pela via do mandado de segurança, a constitucionalidade de projetos de lei ou de emendas à Constituição ${ }^{15}$. Trata-se de modalidade inédita de controle jurisdicional de constitucionalidade, conforme reconheceu o Ministro Gilmar Mendes no julgamento do Mandado de Segurança ${ }^{\circ}$ $24.138^{16}$.

\footnotetext{
${ }^{14}$ MS 20.257, rel. Min. Moreira Alves.

${ }^{15}$ Neste sentido, destacam-se os seguintes precedentes: MS 21.648/DF, MS 21.642/DF, MS 22.487, MS 23.0473/DF, MS 24.356/DF, MS 24.430/DF, MS 24.642/DF, MS 24.430/DF e AG. REG. em MS 21.303 AgR/DF.

16 “".... Trata-se de uma aplicação do que poderia ser considerada como uma variante da 'doutrina brasileira do mandado de segurança', que permite a utilização desse peculiar instrumento de defesa de direitos subjetivos públicos na solução de eventual conflito de atribuições ou de conflito entre órgãos, a Organstreitgkeit do direito constitucional alemão (Lei Fundamental, art. 93, I, nº 1). É, na expressão de Klaus Schlaich, um processo consigo mesmo destinado a dirimir controvérsias entre órgãos constitucionais a propósito de suas competências [...]. Entre nós, a despeito da pouca racionalização em torno do uso diferenciado do mandado de segurança nessa outra dimensão, convém anotar que tal instrumento tem sido utilizado não só para resolver judicialmente conflitos entre órgãos constitucionais, mas, de certa forma, conflitos de atribuição entre órgãos administrativos em geral. No que diz respeito à admissibilidade do controle preventivo de atos normativos, o mandado de segurança opera como autêntico processo de solução de conflitos entre órgãos de perfil constitucional”.
} 
Cabe salientar, entretanto, que em todas as ocasiões em que Supremo se viu provocado a declarar, de forma preventiva, a inconstitucionalidade de um projeto de lei ou emenda constitucional jamais o fez, ainda que tenha admitido cabível o mandado de segurança. Assim, a Corte Constitucional brasileira adotou sempre um perfil marcadamente conservador, desconfiando da intervenção direta em outro Poder.

Essa postura pode ser bem demonstrada pelo teor do voto do Ministro Paulo Brossard, quando do julgamento do Mandado de Segurança ${ }^{\circ}{ }^{21.648:}$

[...] O parlamentar, deputado ou senador, não é obrigado a votar. Ele pode votar a favor ou contra um projeto, bem como pode abster-se de votar. Pode abster-se e dar as razões da sua abstenção: - "Deixo de votar o projeto por entender que ele não pode tramitar na Casa por ofender tal ou qual cláusula da Constituição".

Não tem sentido pedir ao Poder Judiciário lhe conceda mandado de segurança para abster-se de votar. O parlamentar não querendo votar não vota, independente de mandado de segurança. De modo que, prima facie, parece-me que o mandado de segurança seria inteiramente descabido.

Senhor Presidente, continuo firmemente convencido, e cada vez mais convencido, da existência de determinados territórios confiados privativamente a outros poderes e inacessíveis à interferência do Poder constitucionalidade para que possa ter tramitação numa ou outra Casa do Congresso é atribuição precípua do Magistrado que a preside, não é atribuição de outro poder, o Judiciário, por mais eminente e respeitável que ele seja, como é o caso do Supremo Tribunal Federal.

Persisto no entendimento que o judiciário não pode penetrar no âmago de outro Poder, que a Constituição diz separado e distinto, com competência própria, para dizer-lhe que se tal projeto pode ou não pode tramitar. Isto é da incumbência e da responsabilidade do Presidente da Casa, cujas decisões têm um Tribunal de recurso, que é o Plenário. Persistindo nesse plano inclinado, o Supremo Tribunal Federal terminaria por organizar a ordem do dia da Câmara ou do Senado. Aprovado, porém, um projeto de lei, convertido em lei, fica ela sujeita ao crivo, ao exame, à crítica, à análise e até ao poder fulminatório do Poder Judiciário, se houver efetivamente ofensa à Constituição. Mas interferir preventivamente no âmago do Poder Legislativo, regular o processo legislativo que corre fora e longe do Tribunal, é que me parece descaber ao Poder Judiciário $^{17}$.

Neste caso, o Ministro Brossard, que anteriormente havia ocupado posição de destaque no Senado Federal, atinge o próprio âmago da fundamentação do Ministro Moreira Alves, favorável à impetração. Outros Ministros, entretanto, ainda que compactuassem com a medida, ressaltavam sua absoluta excepcionalidade na nossa ordem constitucional. É o caso do Ministro Sepúlveda Pertence, no julgamento do pedido liminar no Mandado de Segurança $n^{\circ} 23.047$ :

\footnotetext{
${ }^{17}$ MS 21.648, rel. Min. Octavio Gallotti.
} 


\begin{abstract}
Cogita-se, no entanto, é fácil de entender, de hipótese excepcionalíssima de controle jurisdicional preventivo de constitucionalidade das normas, ao qual, é de todo avesso o sistema brasileiro.

Há de ser particularmente densa a plausibilidade da arguição (sic) de inadmissibilidade material de uma simples proposta de emenda à Constituição para autorizar o Supremo Tribunal Federal - mormente em juízo liminar - a vedar que sobre ela se manifeste o Congresso Nacional, no exercício do se poder mais eminente, o de reforma constitucional.
\end{abstract}

Esse posicionamento mereceu crítica de Cattoni de Oliveira (2016, p. 28). Para o autor, no que tange ao controle da regularidade do processo legislativo, a jurisprudência do Supremo oscila "entre um formalismo jurídico e uma desjuridicização das questões de regularidade regimental do processo legislativo". Por formalismo jurídico, Oliveira quer indicar o modo como o Tribunal isola os atos processuais legislativos da cadeia procedimental a que pertencem.

A perspectiva formalista é bem ilustrada pela superação da Súmula $n^{\circ} 5$, na qual o Tribunal assentou o entendimento de que a sanção do projeto de lei supria a falta de inciativa do Poder Executivo. Ao compreender a sanção como independente das demais fases do processo legislativo, a Corte concluiu que a sanção posterior do Executivo não poderia convalidar o vício de inciativa (OLIVEIRA, 2016, p. 29).

A desjuridicização, por sua vez, "consubstancia-se por meio do alargamento da noção do que seja matéria interna corporis, como o são as questões de regularidade regimental" (PEREIRA, 2012, p. 160). Deste modo, o controle judicial poderia ocorrer apenas "se imediatamente referido a requisitos procedimentais previstos diretamente pelo Texto constitucional"18 (OLIVEIRA, 2016, p. 30).

A verdade é que nos primeiros anos de vigência da Constituição de 1988 o Supremo Tribunal Federal não havia respondido àquilo que Campos (2014, p. 240) denominou de disposição ativista, favorecida pelo texto constitucional. Pelo contrário, as primeiras decisões pós-1988 "deram a impressão de que a Corte manteria o recentíssimo passado de passividade judicial" (CAMPOS, 2014, p. 241).

\footnotetext{
${ }^{18}$ Assim, por não haver previsão constitucional expressa, o Supremo Tribunal Federal já manifestou entendimento que a não observância do prazo regimental entre os turnos de votação não implica em inconstitucionalidade formal: “A aprovação de emendas à Constituição não recebeu da Carta de 1988 tratamento específico quanto ao intervalo temporal mínimo entre os dois turnos de votação $\left(\mathrm{CF}\right.$, art. $\left.62, \S 2^{\circ}\right)$, de sorte que inexiste parâmetro objetivo que oriente o exame judicial do grau de solidez da vontade política de reformar a Lei Maior. A interferência judicial no âmago do processo político, verdadeiro locus da atuação típica dos agentes do Poder Legislativo, tem de gozar de lastro forte e categórico no que prevê o texto da Constituição Federal. Inexistência de ofensa formal à Constituição brasileira" (ADI 4357, rel. Min. Ayres Britto, rel. p/ Acórdão: Min. Luiz Fux, j. em 14/03/2013).
} 
No entanto, com a entrada do novo milênio, o Tribunal gradualmente abandonou sua ortodoxia de autorrestrição judicial, adotando, ao contrário, uma posição muito mais ativista (CAMPOS, 2014, p. 247). Nestas condições, ele tem sido chamado a atuar em questões morais e políticas relevantes e justamente essa tendência de judicializar o debate político colocou em destaque a questão do controle judicial preventivo.

É importante salientar que o espaço para a intervenção do Judiciário foi ampliado pós1988. Quando o Supremo construiu seu precedente acerca da possibilidade de controle de constitucionalidade sobre o processo legislativo, as cláusulas pétreas previstas na Constituição eram apenas duas: a federação e a república. Atualmente, esse rol foi significativamente ampliado, incluindo cláusulas bastante abstratas como, por exemplo, a "separação de poderes" e os "direitos e garantias individuais"19.

\section{DOIS EXEMPLOS DA ATUAÇÃO DO SUPREMO NO CONTROLE PREVENTIVO DE CONSTITUCIONALIDADE}

No dia 24 de abril de 2013, a Comissão de Constituição e Justiça (CCJ) da Câmara dos Deputados aprovou o Projeto de Emenda Constitucional (PEC) n 33/2011 que, conforme ementa $^{20}$, "altera a quantidade mínima de votos de membros de tribunais para declaração de inconstitucionalidade de leis; condiciona o efeito vinculante de súmulas aprovadas pelo Supremo Tribunal Federal à aprovação pelo Poder Legislativo e submete ao Congresso Nacional a decisão sobre a inconstitucionalidade de Emendas à Constituição"21.

\footnotetext{
${ }^{19}$ No julgamento da medida cautelar na ADI 939, o Ministro Moreira Alves chamou a atenção para a abrangência das cláusulas pétreas da Constituição de 1988: “[...] tenho sérias dúvidas a respeito do alcance das denominadas 'cláusulas pétreas' a que se refere o $\S 4^{\circ}$ do artigo 60 da Constituição. Principalmente no tocante à cláusula pétrea concernente aos direitos e garantias individuais, se se considerarem como tais não só os constantes nos setenta e sete incisos do artigo $5^{\circ}$, mas também os demais direitos e garantias expressos na Carta Magna, bem como os decorrentes do regime de princípios por ela adotados, ou dos tratados internacionais em que a República Federativa do Brasil seja parte. Só essa cláusula petrificaria quase toda a Constituição, além de petrificar os tratados - que persistiriam ainda quando denunciados - de que decorram direitos e garantias" (ADI-MC 939, rel. Min; Sydney Sanches).

${ }^{20}$ Disponível em http://www.camara.gov.br/proposicoesWeb/prop_mostrarintegra?codteor=876817\&filename $=$ PEC $+33 / 2011$.

${ }^{21}$ Em 31 de janeiro de 2015, a PEC foi arquivada, em razão do término da legislatura, nos termos do art. 105 do Regimento Interno da Câmara dos Deputados.
} 
Imediatamente, parte significativa da comunidade jurídica levantou-se contra o que foi definido, pelo Ministro Marco Aurélio, como uma "retaliação" do Congresso Nacional em razão do julgamento da Ação Penal n 470 pelo Supremo Tribunal Federal ${ }^{22}$. Segundo outro Ministro da corte, Gilmar Mendes, aprovada a proposta, seria "melhor fechar o Supremo Tribunal Federal". O Ministro defendeu que a proposta "é inconstitucional do começo ao fim, de Deus ao último constituinte que assinou a Constituição"23.

A PEC, segundo seus críticos, constituía uma ameaça ao equilíbrio de Poderes construído pelo constituinte de 1988, ao submeter um Poder, o Judiciário, a outro, o Legislativo. Em nota, o presidente da Associação dos Juízes do Rio Grande do Sul (AJURIS), Pio Giovani Dresch, afirmou que "a PEC 33 atenta contra o princípio da separação dos Poderes, usurpando do Judiciário parte de sua competência exclusiva, que é a de julgar"24.

Ocorre que, na mesma data em que a PEC 33 foi aprovada, o Ministro Gilmar Mendes concedeu liminar no Mandado de Segurança $n^{\circ}$ 32.033, suspendendo a tramitação do Projeto de Lei Complementar 14/2013 no Senado Federal. Limongi (2013, p. 8-A) afirmou que a "opinião pública não foi informada dos vícios formais identificados pelo ministro Gilmar Mendes”. Segundo Silva (2013, p. 18-A), “Gilmar Mendes simplesmente decidiu que o Senado não poderia deliberar sobre um projeto de lei porque ele, Gilmar Mendes, não concorda com o teor do projeto".

Tratava-se de mandando de segurança preventivo, com pedido liminar, impetrado pelo Senador Rodrigo Rollemberg contra o Projeto de Lei $n^{\circ}$ 4.407/2012. O projeto estabelecia que “a migração partidária que ocorrer durante a legislatura, não importará na transferência dos recursos do fundo partidário e do horário de propaganda eleitoral no rádio e na televisão". O objetivo era restaurar o status quo vigente antes de uma intervenção do Supremo na distribuição do horário eleitoral gratuito. O tempo de propaganda eleitoral e os recursos do fundo partidário são proporcionais ao tamanho da bancada do partido na Câmara dos Deputados, o que gerava um incentivo à migração partidária.

\footnotetext{
22 Disponível em http://g1.globo.com/politica/noticia/2013/04/ministros-criticam-pec-que-autoriza-legislativovetar-decisoes-do-stf.html

23 Disponível em http://noticias.terra.com.br/brasil/politica/para-gilmar-mendes-e-melhor-fechar-stf-selegislativo-aprovar-pec-33,3828c2f4e634e310VgnVCM20000099cceb0aRCRD.html

${ }^{24}$ Disponível em http://www.ajuris.org.br/index.php?option=com_content\&view=article\&id=2950:nota-publicaajuris-contra-pec- $33 \&$ catid $=54$ :destaques $\&$ Itemid $=50$
} 
Para o Ministro Gilmar Mendes, “a aprovação do projeto de lei em exame significará [...] o tratamento desigual de parlamentares e partidos políticos em uma mesma legislatura", o que configuraria uma ofensa "à lealdade da concorrência democrática". Além disso, a "singular celeridade da tramitação" indicaria uma "tentativa casuística de alterar as regras para criação de partidos na corrente legislatura, em prejuízo de minorias políticas e, por conseguinte, da própria democracia" 25 .

Ao impedir a transferência dos recursos do fundo partidário e do horário de propaganda eleitoral junto com o parlamentar, o Congresso não só deixava de incentivar a migração partidária, como também mantinha intacta a vontade do eleitor, manifestada nas eleições (LIMONGI, 2013, p. 8-A). Assim, ao barrar a tramitação da proposta parlamentar, o Ministro Gilmar Mendes, mesmo que temporariamente, interferiu de forma direta na agenda política do parlamento.

Posteriormente, o plenário da Corte, por maioria, indeferiu o mandado de segurança, vencidos os Ministros Gilmar Mendes, Celso de Mello e Dias Tóffoli ${ }^{26}$. O voto vencedor, elaborado pelo Ministro Teori Zavascki, destacou a excepcionalidade do controle preventivo, que seria admitido na jurisprudência do Tribunal em apenas duas situações: 1) em caso de manifesta ofensa à cláusula pétrea por proposta de emenda constitucional; ou 2) quando na tramitação "for verificada manifesta ofensa a alguma das cláusulas constitucionais que disciplinam o correspondente processo legislativo" 27.

Tirando essas hipóteses, por "mais evidente e grotesca" que seja a inconstitucionalidade material, o Tribunal não teria legitimidade para interferir no processo legislativo. E isso por duas razões, consignadas no voto do Ministro Zavascki: $1^{\circ}$ ) a presunção de que o Legislativo é incapaz de corrigir a inconstitucionalidade durante a tramitação, retirando sua competência de exercer o controle de constitucionalidade; e $2^{\circ}$ ) a possibilidade de, aprovada a lei, se "provocar o controle repressivo pelo Judiciário, para negar-lhe validade, retirando-a do ordenamento jurídico" 28 .

\footnotetext{
${ }^{25}$ MS 32.033/MC, rel. Min. Gilmar Mendes.

${ }^{26}$ O projeto de lei então foi aprovado pelo Poder Legislativo e sancionado pela Presidente da República, convertendo-se na Lei ${ }^{\circ} 12.875$, de 30 de outubro de 2013.

${ }^{27}$ MS 32.033, rel. Min. Teori Zavascki.

${ }^{28}$ MS 32.033, rel. Min. Teori Zavascki.
} 
Mais recentemente, o Ministro Luiz Fux deferiu liminar no Mandado de Segurança $n^{\circ}$ 34.530, impetrado pelo Deputado Federal Eduardo Bolsonaro, suspendendo a tramitação do Projeto de Lei no 4.850/2016, denominado "10 Medidas Contra a Corrupção". Tratava-se de projeto de lei de iniciativa popular, encabeçado pelo Ministério Público Federal, que visava propor alterações na legislação penal com o intuito de endurecer o combate à corrupção ${ }^{29}$.

$\mathrm{Na}$ Câmara de Deputados o projeto de lei recebeu diversas emendas parlamentares, em especial um substitutivo que previa a tipificação do crime de abuso de autoridade praticado por magistrados e membros do Ministério Público. O substitutivo, não obstante ter sido duramente criticado pela Associação dos Magistrados Brasileiros ${ }^{30}$ e pelos responsáveis pela "Operação Lava-Jato" 31 , foi aprovado e encaminhado para o Senado Federal.

Todavia, para o Ministro Fux, a tramitação do projeto de lei deveria ser interrompida liminarmente por conta de uma "multiplicidade de vícios", entre os quais destacou os seguintes:

(1) por se tratar de iniciativa popular, o projeto de lei não poderia ter sido subscrito por parlamentares. Na opinião do Ministro, desprovida de qualquer fundamento jurídico, a "assunção da titularidade do projeto por parlamentar [...] amesquinha a magnitude democrática e constitucional da iniciativa popular, subjugando um exercício por excelência da soberania pelos seus titulares aos meandros legislativos nem sempre permeáveis às vozes das ruas" ${ }^{23}$.

(2) além disso, esse tipo de projeto, indicou o Ministro, deve ser debatido em sua essência, de modo que a apresentação de emendas e substitutivos dos Deputados Federais é vedada, pois desfiguram "a proposta original para simular apoio público a um texto essencialmente dis-

\footnotetext{
${ }^{29}$ Entre as medidas propostas, em grande parte criticadas por juristas, estavam a utilização da prisão preventiva para assegurar a devolução do dinheiro desviado, o "ajuste" nas nulidades penais e a reforma no sistema de prescrição penal.

${ }^{30}$ Na perspectiva do Presidente da Associação dos Magistrados Brasileiros, João Ricardo Costa, "o parlamento não perde a oportunidade de criar mecanismos de retaliação ao Poder Judiciário". Texto disponível em: http://www.amb.com.br/amb-acompanha-apresentacao-do-parecer-do-projeto-das-medidas-anticorrupcao/

${ }^{31}$ Segundo nota oficial assinada pelos integrantes da força-tarefa da Operação Lava-Jato, a tipificação dessas condutas teria como objetivo intimidar o Ministério Público e o Poder Judiciário e impedir o combate à corrupção. Segundo os signatários, que inclusive ameaçaram abandonar as investigações caso o projeto fosse aprovado, o "avanço de propostas como a Lei da Intimidação instaura uma ditadura da corrupção, um estado de tirania em que o poder é exercido fora dos limites com os quais foi conferido pelo povo, isto é, fora da circunscrição do atendimento ao interesse público". Texto disponível em: https://www.conjur.com.br/2016-nov-30/mpf-ameacaabandonar-lava-jato-abuso-autoridade-for-aprovado

${ }^{32}$ MS 34.530, rel. Min. Luiz Fux.
} 
tinto do subscrito por milhões de eleitores". Para o magistrado, essa prática desvirtuaria o instituto, configurando-se "evidente sobreposição do anseio popular pelos interesses parlamentares ordinários" $" 33$.

(3) por fim, as referidas emendas teriam incorporado ao texto do projeto de lei matéria que seria estranha ao seu conteúdo originário, ofendendo o princípio democrático e o devido processo legal. Na fundamentação, o Ministro utiliza o precedente das emendas “jabuti”, apelido pelas quais ficaram conhecidas as emendas acrescentadas por parlamentares nas medidas provisórias editadas pelo Chefe do Executivo, sem relação com o seu tema central ${ }^{34-35}$.

Mais adiante, em sua decisão, o magistrado faz uma crítica ao conteúdo do ato impugnado, apontando que a emenda de Plenário, aprovada pela Câmara dos deputados, implicava uma "desnaturação da essência da proposta popular destinada ao combate à corrupção". Na realidade, a proposta legislativa, na visão do Ministro, representava uma "preocupante atuação parlamentar contrária a esse desiderato" ${ }^{36}$.

A decisão do Supremo Tribunal Federal foi recebida com perplexidade pelo Presidente da Câmara dos Deputados ${ }^{37}$. Afinal, a prática de subscrição dos projetos de lei de iniciativa popular por parlamentares é prática comum, justamente par a evitar que a Casa tivesse que conferir os dados dos dois milhões de signatários do projeto, como determina o artigo 252 do Regimento Interno da Câmara dos Deputados.

Cumpre salientar que todos os projetos de iniciativa popular anteriores foram aprovados nesse tipo de coautoria da iniciativa popular e parlamentar (ou do Executivo) ${ }^{38}$. Tal dado, inclusive, era do conhecimento do Ministro Fux, na medida em que ele pondera que sua decisão

\footnotetext{
${ }^{33}$ MS 34.530, rel. Min. Luiz Fux.

${ }^{34}$ O leading case citado pelo Ministro Fux foi a ADI 5127, em que a Confederação Nacional das Profissões Liberais questionava as alterações feitas na MP 472/2009, convertida na Lei ${ }^{\circ} 12.249 / 2010$, que resultaram na extinção da profissão de técnico em contabilidade. A medida provisória em questão tratava de vários assuntos, inclusive sobre o programa "Minha Casa, Minha Vida“, nenhum deles guardando qualquer relação com a profissão de contador.

${ }^{35}$ Segundo o Ministro Fux, "se há afronta aos preceitos democráticos e ao devido processo legislativo quando o Parlamento desvirtua o conteúdo de projeto cunhado pelo Chefe do Executivo, com maior razão a citada afronta existe nos casos de distorção da matéria versada em proposta de iniciativa popular" (MS 34.530).

${ }^{36}$ MS 34.530, rel. Min. Luiz Fux.

${ }^{37} \mathrm{http}$ ///agenciabrasil.ebc.com.br/politica/noticia/2016-12/camara-enviara-ao-stf-explicacoes-sobre-votacao-delei-contra-corrupcao

${ }^{38}$ Apenas quatro projetos de lei de iniciativa popular foram aprovados desde 1988: (1) a Lei ${ }^{\circ}$ 8.930/1994, que modificou a lei dos crimes hediondos e contou com mais de um milhão e trezentas mil assinaturas, mas que foi encaminhada pelo Poder Executivo (Mensagem $n^{\circ} 571$ ); (2) a Lei $n^{\circ}$ 9.840/1999, que estabeleceu o crime de
} 
não alcança "leis já aprovadas em desacordo com os preceitos ora firmados", mas "apenas os projetos de lei ainda não publicados após sanção do Presidente da República ou derrubada do veto" 39 .

Outro ponto interessante da decisão do Ministro Fux foi o fato de ele ter utilizado entre seus argumentos a transgressão às normas regimentais da Câmara dos Deputados. A jurisprudência do Supremo, seguida inclusive pelo próprio Ministro até então, sedimentou o entendimento de que "o Poder Judiciário não possui competência para sindicar atos das Casas Legislativas que se sustentam, unicamente, na interpretação conferida às normas regimentais internas" $" 40$.

Agora, no entanto, o Ministro Fux reconhecia que as "disposições regimentais consubstanciam, em tese, autenticas normas jurídicas e, como tais, são dotadas de imperatividade e de caráter vinculante". Nestes termos, é impróprio o entendimento de que a transgressão das normas regimentais seriam “questões interna corporis, imunes ao controle judicial”. Pelo contrário, a violação do regimento "habilita a pronta e imediata resposta do ordenamento jurídico"41.

Em sua decisão, o Ministro Fux não procurou exercer o controle judicial visando garantir a regularidade do devido processo legislativo, mas discutir o próprio mérito das escolhas legislativas $^{42}$. Na realidade, transpareceu que a intenção do Ministro, ao interromper o processo le-

compra de votos e que foi subscrita por diversos parlamentares antes de alcançar o número de assinaturas exigidas, para que pudesse ser aplicada já nas eleições de 2000; (3) a Lei no 11.124/2005 que criou o "Fundo Nacional para Morada Popular", que tramitava no Congresso Nacional desde 1992 e (4) a Lei Complementar no 135/2010, a "Lei da Ficha Limpa", que se originou de um projeto de lei do Executivo, mas foi subscrita por diversos deputados federais e contou com o apoio de um milhão e setecentos mil assinaturas.

${ }^{39}$ MS 34.530, rel. Min. Luiz Fux.

${ }^{40}$ MS 35.581, rel. Min. Luiz Fux. Ver nota 18, acima.

${ }^{41}$ MS 34.530, rel. Min. Luiz Fux. Aqui o Ministro rejeita uma antiga tese, defendida por Manoel Gonçalves Ferreira Filho (2012, p. 276), de que "se a observância dos preceitos constitucionais é rigorosa, absoluta, a dos regimentais não o é".

${ }^{42}$ Por outro lado, no julgamento colegiado do já referido MS n ${ }^{\circ} 32.033$, o Ministro Fux adotou posição diametralmente oposta, criticando o voto do Ministro Gilmar Mendes: "[...] acolher o pedido deduzido pelo Impetrante, de sorte a suspender a tramitação do PLC $\mathrm{n}^{\circ} 14 / 93$, é extinguir o debate. E isso não pode ser tolerado e não é o que se espera de uma Corte Constitucional. [...] É no Parlamento, e não no Poder Judiciário, que as discussões públicas devem ocorrer por excelência. Não se trata de um argumento acaciano, mas, ao revés, de um postulado ínsito à democracia, que não pode ser negligenciado. No caso vertente, não se sabe se o projeto de lei será arquivado, alterado ou aprovado. A questão deve permanecer em discussão, sob pena de um paternalismo judicial ou, para utilizar uma expressão bastante em voga, uma supremocracia". 
gislativo, foi apenas atender aos interesses corporativos do Ministério Público Federal e da Magistratura, que enxergaram no projeto de lei uma tentativa do Congresso Nacional em controlar seus poderes ${ }^{43}$.

Esses episódios se somam a outras intervenções diretas, sempre liminares, do Supremo Tribunal Federal nas funções de outro Poder, no caso o Legislativo. Por vezes, essas decisões são denunciadas pelo seu casuísmo e ausência de integração com outros julgados da Corte ${ }^{44}$. Mas pode-se ir mais adiante e se perguntar se a extensão dessas intervenções não acaba por colocar em discussão não apenas a legitimidade dos demais poderes, mas também a própria configuração institucional desenhada pelo poder constituinte originário.

\section{JUDICIALIZAÇÃO DA POLÍTICA, ATIVISMO JUDICIAL E LEGITIMIDADE DEMOCRÁTICA}

Nas palavras de Veríssimo (2008, p. 408), parece haver uma “espécie de 'fuga' cada vez mais acelerada dos temas políticos (de política pública, de ação governamental executiva, de política representativo-partidária) para dentro do direito e, deste, para dentro dos órgãos judiciários". Nos últimos anos, as indicações dos componentes do Supremo têm sido precedidas de intensas especulações pela mídia e seus julgamentos acompanhados com enorme interesse pela opinião pública ${ }^{45}$.

Pode-se analisar a judicialização da política por um duplo aspecto: o social e o institucional. Segundo Vianna et al (1999, p. 15), a judicialização, do ponto de vista social, tem origem

\footnotetext{
${ }^{43}$ Como de costume, o Ministro Gilmar Mendes comentou a decisão do colega, nos seguintes termos: "Temos que ter cuidado para não parecer que estamos olhando só para nossos próprios umbigos, querendo resolver nossos próprios problemas, de procuradores, de juízes. É preciso ter muito cuidado para não parecermos corporativos". Disponível em: https://oglobo.globo.com/brasil/gilmar-mendes-diz-que-stf-tem-que-ter-cuidado-para-naoparecer-corporativista-20662761

${ }^{44}$ É nesse sentido a crítica de Limongi (2013, p. 8-A). Falando especificamente das intervenções do Supremo no terreno da legislação eleitoral e partidária, que "carecem de coerência", o cientista político afirma que "a proposta do deputado Edinho Araújo (PMDB-SP) e a emenda do DEM [presentes no Projeto de Lei Complementar ${ }^{\circ}$ 14/2013] são reações a um 'casuísmo' [do STF]. O Supremo alterou as regras do jogo. Difícil sustentar que a intervenção do Judiciário tenha contribuído para fortalecer os partidos e aperfeiçoar a democracia. Basicamente, a proposta, que o ministro Gilmar barrou antes que sua tramitação chegasse a termo, simplesmente restaurava o status quo".

${ }^{45}$ Nessas condições, segundo Ferejohn (2012, p. 91), “aqueles interessados em decisões têm motivos para buscar influenciar e, se possível, controlar as nomeações para os tribunais e outras instituições jurídicas. Nesse sentido, a 'judicialização' da política tende a produzir a politizações dos tribunais”.
} 
a partir de um processo de marcante publicização da esfera privada. $\mathrm{O}$ significativo aumento da complexidade das relações sociais exige uma resposta do legislador, com a criação de novos direitos. Por consequência, verifica-se um aumento significativo da litigiosidade, que deságua no Poder Judiciário.

$\mathrm{O}$ aspecto institucional, diz respeito ao papel de destaque que as Cortes Constitucionais e a própria Constituição passam a exercer na contemporaneidade, em especial no Brasil. Barroso (2009, pp. 332-334) aponta três causas principais: a redemocratização, a constitucionalização abrangente e a abrangência do sistema brasileiro de controle de constitucionalidade ${ }^{46}$. Esses fenômenos, conjuntamente, levaram o Poder Judiciário e, em especial, o Supremo Tribunal Federal, para a ribalta do debate político.

Outro fator significativo para a crescente judicialização da política é decorrente das escolhas, interesses ou considerações estratégicas dos agentes políticos. Afinal, em geral, os próprios partidos políticos recorrem ao Poder Judiciário com o intuito de solucionar controvérsias políticas $^{47}$. Taylor e Da Ros (2008, pp. 838-43) identificam três usos da judicialização pelos atores políticos: 1) como tática de oposição ${ }^{48}$; 2) como arbitragem de interesses em conflito ${ }^{49}$; e 3) como instrumento de governo ${ }^{50}$.

Além do mais, parece haver um interesse cada vez maior dos agentes políticos delegar autoridade política aos tribunais para "transferir responsabilidade e, com isso, reduzir os riscos

\footnotetext{
${ }^{46}$ Vieira (2008, pp. 446-447) aponta diagnóstico semelhante: para este autor, a ambição da Constituição de 1988, que, com sua desconfiança do legislador, legislou sobre quase tudo; e as competências superlativas do Supremo Tribunal Federal, a quem cabe a tarefa de Corte Constitucional e tribunal recursal de última instância, criaram as condições para que se estabelecesse no Brasil uma supremocracia, termo criado por ele para designar o papel preponderante que o Tribunal ocupa na vida política-institucional do País.

${ }^{47}$ Segundo levantamento de dados efetuado por Costa e Costa (2018, p. 153), os partidos políticos são responsáveis pelo ajuizamento de $16,4 \%$ das ações em controle concentrado de constitucionalidade.

${ }^{48}$ A judicialização como tática de oposição política pode ser entendida como a utilização dos tribunais "com o propósito de declarar oposição ou desmerecer políticas públicas adotadas pelo governo. [...] Em todos os casos, trata-se de empregar os tribunais, literalmente, como uma última instância, à qual se pode recorrer para derrotar determinadas políticas, denunciar as práticas do governo e tornar clara a posição contrária de determinados grupos a estas" (TAYLOR; DA ROS, 2008, p. 838).

${ }^{49}$ A judicialização como arbitragem surge quando há a redistribuição legal de "poderes e atribuições entre diferentes entidades e instituições, como partidos políticos, entes federativos e diferentes instâncias do Poder Judiciário" (TAYLOR; DA ROS, 2008, p. 840). Nesse caso, a judicialização não pretende desmerecer a política pública adotada, mas estabelecer regras procedimentais que sejam benéficas para determinados atores políticos.

${ }^{50} \mathrm{Na}$ judicialização como instrumento de governo, busca-se "a 'mão amiga' da instituição máxima do Poder Judiciário para que esta implemente ou se pronuncie de forma favorável a políticas públicas do próprio governo" (TAYLOR; DA ROS, 2008, p. 842). O tribunal, nesse caso, pode agira de forma direta, anulando estatutos legais que não sejam do interesse do governo, ou de forma indireta, superando situações de paralisia decisória ou de impasse legislativo.
} 
a si próprios e ao aparato institucional dentro do qual trabalham". Ao transferir as "batatas quentes" para os tribunais, os políticos podem aumentar sua legitimidade ou reduzir sua culpabilidade na tomada de decisões ou, simplesmente, optar por não tomar decisão alguma em matérias difíceis (HIRSCHL, 2012, p. 48).

Assim, pode-se verificar que a judicialização é um fenômeno inexorável, decorrente da complexidade das sociedades modernas e do papel institucional que a Constituição relegou ao Poder Judiciário. Essa circunstância repercutiu no modo de conceber a atuação dos juízes e tribunais, implicando em uma "maior interferência no espaço de atuação dos outros dois Poderes” (BARROSO, 2009, p. 335). Daí resta um “Judiciário 'ativista', que não se constrange em exercer competências de revisão cada vez mais amplas” (VERÍSSIMO, 2008, p. 422).

A resposta de alguns integrantes da Corte a esse processo de extrema judicialização do espaço político é uma postura cada vez mais ativista, que, conforme pretendemos demonstrar, coloca em risco a engenharia institucional desenhada pelo constituinte de 1988. Se esta nova atitude foi essencial para que se consolidasse uma série de direitos fundamentais, é inegável que ela gerou importantes focos de tensão entre o Poder Judiciário e o Legislativo.

O ativismo judicial difere da judicialização, na medida em que "é uma atitude, a escolha de um modo específico e proativo de interpretar a Constituição, expandido o seu sentido e alcance" (BARROSO, 2009, p. 335). Garapon (1998, p. 54), um dos seus grandes incentivadores, afirma que "o ativismo começa quando, entre várias soluções possíveis, a escolha do juiz é dependente do desejo de acelerar a mudança social ou, pelo contrário, de a travar".

A distinção ${ }^{51}$ entre ativismo judicial e judicialização da política foi sintetizada por Streck (2011, p. 589): enquanto a judicialização é um “fenômeno que exsurge a partir da relação entre os Poderes do Estado", o ativismo acontece quando um juiz “decide a partir de argumentos de

\footnotetext{
${ }^{51}$ É importante reconhecer, entretanto, que existem importantes divergências doutrinárias quanto essa distinção. Rodriguez (2013, p. 183), por exemplo, afirma que "embora aparentem ser ideias bastante diferentes entre si, 'judicialização da política' e 'ativismo judicial' são como lados de uma mesma moeda, de um processo visto ora da perspectiva da política que seria 'invadida' pela lógica judicial, ora da perspectiva do próprio 'invasor"'. A partir de outra perspectiva, Torrano $(2015$, p. 197) destaca que, "ao menos no Brasil, a distinção entre judicialização da política e ativismo judicial por vezes soa artificial: ela foi realizada por aqueles mesmos teóricos do 'pós-positivismo' que, desde a década de noventa, têm considerado o Poder Judiciário como um tipo de Poder 'Paternalista', encarregado de corrigir distorções morais, econômicas, políticas e sociais a partir de técnicas mágicas como 'a nova hermenêutica' e o apelo a 'princípios".
} 
política, de moral, enfim, quando o direito é substituído pelas convicções pessoais de cada magistrado".

Entre outras, a postura ativista se caracteriza pela (1) aplicação direta da Constituição a situações não contempladas de forma expressa em seu texto; (2) a declaração de inconstitucionalidade de atos normativos com base em critérios menos rígidos do que a violação literal da Constituição e (3) imposição de condutas ou de abstenções ao Poder Público (BARROSO, 2009 , p. 335). Essas características distanciaram o juiz constitucional do "legislador negativo" preconizado por Kelsen ${ }^{52}$.

Deste modo, enquanto a judicialização da política "não parece ter sido [...] um resultado imprevisto do novo arranjo constitucional” (VERÍSSIMO, 2008, p. 408), o ativismo surge como uma espécie de solução messiânica que atribui a um dos poderes constituídos uma competência desmedida. Abre-se o caminho para a discricionariedade e arbitrariedade judicial. Mais ainda, ao confiar ao Poder Judiciário (e em especial ao Supremo Tribunal Federal) a tarefa de "superego da sociedade" se reduz em grande medida o espaço público deliberativo ${ }^{53}$.

No caso brasileiro, essa postura ativista do Poder Judiciário é agravada por uma incorporação idealista ou ingênua do pós-positivismo ou neoconstitucionalismo ${ }^{54}$ (CAMPOS, 2014, p. 271). Sua justificativa é a superação do modelo positivista pela "Teoria dos Princípios" trada no pensamento de Alexy e Dworkin. Na versão deturpada dos defensores dessa tese, “os

\footnotetext{
${ }^{52}$ Nas palavras de Kelsen (2013, pp. 151-2), “[...] anular uma lei é estabelecer uma norma geral, porque a anulação de uma lei tem o mesmo caráter de generalidade que sua elaboração, nada mais sendo, por assim dizer, que a elaboração com sinal negativo e portanto ela própria uma função legislativa. E um tribunal que tenha o poder de anular as leis é, por conseguinte, um órgão do poder legislativo".

${ }^{53}$ Segundo Maus (2000, p. 201), "quando a Justiça - em todas as suas instâncias — decide questões morais polêmicas a partir de pontos de vista morais, pratica deste modo a "desqualificação" da base social. O formalismo jurídico clássico ainda dispunha de espaço jurídico livre: o que não era compreendido por disposição legal do respectivo direito válido situava-se estritamente fora do âmbito jurídico, e portanto fora do alcance jurídico do Estado - ao menos sob as condições do Estado de direito. Somente quando a jurisprudência trata seus próprios pontos de vista morais como regras jurídicas é que qualquer fato imaginável pode ser identificado como juridicamente relevante e transformado em matéria de decisão judicial. Com isso o poder de sanção do Estado expande-se, vindo de encontro a exigências que, de acordo com o entendimento clássico do Estado de direito, somente valiam como exigências morais, ficando legadas à problematização social imanente. Que desta forma os espaços jurídicos autônomos desapareçam é tão notável quanto o fato de que na sociedade atual a integração jurídica dos aparelhos do Estado e a integração moral das relações vitais concretas permaneçam ainda acentuadamente independentes umas das outras".

${ }^{54}$ A expressão pós-positivismo idealista é de Torrano (2015, p. 98-9).

${ }^{55}$ Para Brandão (2012, p. 136), a "incorporação entusiástica da Teoria dos Princípios" se deu "a partir das obras percursoras de Paulo Bonavides e de Eros Roberto Grau, publicadas em meados da década de 1990". Segundo o mesmo autor, "a introdução de teorias pós-positivistas no Brasil suscitou verdadeira febre de trabalhos sobre Teorias dos Princípios, ponderação de interesses, teorias da argumentação, proporcionalidade e razoabilidade
} 
princípios 'moralmente corretivos' podem determinar a não aplicação de uma regra jurídica válida, ao bem da equidade ou de outro valor tido pelo intérprete como inegociável para o progresso moral” (TORRANO, 2015, p. 99).

Um exemplo significativo desse discurso pode ser encontrado em um artigo recente da lavra do Ministro Luís Roberto Barroso, talvez um dos maiores defensores do neoconstitucionalismo no direito brasileiro. Para ele, as cortes constitucionais exercem três papéis fundamentais: contramajoritário, representativo e iluminista. Por iluminista, Barroso (2018, p. 2208) quer afirmar "uma razão humanista que conduz o processo civilizatório e empurra a história na direção do progresso social e da liberação de mulheres e homens".

Caberia aos tribunais constitucionais, então, provavelmente imbuídos daquilo que Hegel denominava de "astúcia da razão" (List der Vernunft), realizar o ideal civilizatório consagrado no texto constitucional, sempre quando os demais poderes se opuserem ao progresso. Nas palavras de Barroso (2018, p. 2209):

O poder dominante, como regra geral, emana da vontade majoritária e das instituições através das quais ela se manifesta, que são o Legislativo e o Executivo. Vez por outra, no entanto, é preciso acender luzes na escuridão, submeter a vontade à razão. Nesses momentos raros, mas decisivos, as cortes constitucionais podem precisar ser os agentes da história.

Nesses termos, embora o Poder Judiciário não possua a exclusividade em matéria de interpretação constitucional, sua “exegese [...] constitui um 'precedente vinculante' para a [...] interpretação constitucional perpetrada pelos 'poderes' (especialmente pelo Parlamento) e pela sociedade civil”" (BRANDÃO, 2012, p. 15). Afinal, o Judiciário possuíra "condições para tomar decisões melhores do que as dos demais 'poderes' na interpretação e toda e qualquer norma constitucional” (BRANDÃO, 2012, p. 23), de onde adviria sua autoridade.

É inegável que a atual Constituição brasileira deu ao Poder Judiciário lugar de destaque, em especial ao Supremo Tribunal Federal. A ele compete, conforme inscrito no caput do art. 102, "precipuamente, a guarda da Constituição", inclusive superando normativamente a controvérsia Kelsen x Schmitt ${ }^{56}$. No entanto, dessa posição privilegiada não advém imediatamente

etc., além da aplicabilidade imediata dos direitos fundamentais, sobretudo os sociais. Substitui-se a ênfase nos enunciados normativos, típica dos constitucionalismos da efetividade, por uma argumentação moral, calcada em valores morais e na democracia" (BRANDÃO, 2012, pp. 136-7).

56 Durante os anos de 1930, os dois teóricos travaram uma discussão sobre a quem competia a guarda da constituição. Para Schmitt, a defesa da constituição, entendida como unidade política de um povo, não pode ficar 
o propalado direito à última resposta, tão festejado pelos integrantes da Corte em seus votos e manifestações ${ }^{57}$.

Como coloca Brandão (2012, p. 24), “a autoridade para dar a 'última palavra' sobre a interpretação constitucional não é absoluta nem estável". Ainda que se possa defender que o desenho institucional adotado pelo constituinte dê ao Supremo a "última palavra", essa não pode ser outra coisa senão provisória. Entender de forma contrária "é prejudicial não apenas porque rejeita a participação genuína do legislador na formulação do significado constitucional, mas também porque lhe confere uma isenção de responsabilidade” (MENDES, 2011, p. 218).

Desse modo, a interferência cada vez mais frequente no processo legislativo tem como consequência um enfraquecimento do Poder Legislativo e a substituição da agenda política por uma agenda do Poder Judiciário. Assim, questiona-se a atuação do Supremo Tribunal Federal, por uma "indevida" intervenção nas funções legislativa e executiva, em detrimento da distribuição constitucional de competências, pela centralização da interpretação em prejuízo dos demais órgãos jurisdicionais e pelo potencial lesivo que esta representa para o incipiente arranjo democrático.

\footnotetext{
a cargo de uma jurisdição constitucional, que ele denomina de "solução austríaca" (SCHMITT, 1998, p. 33), porque "a institucionalização de semelhante protetor da Constituição seria diametralmente oposta à consequência política do princípio da democracia" (SCHMITT, 1998, p. 244). Tal autoridade, portanto, devia ser concedida ao Presidente do Reich porque ele "se encontra no centro de um sistema - construído sobre fundamentos plebiscitários - de neutralidade e independência em relação aos partidos políticos" (SCHMITT, 1998, p. 249). De uma perspectiva completamente oposto, Kelsen critica a solução de Schmitt, apoiando-se em "uma separação a mais rigorosa possível entre conhecimento científico e juízo de valor político" (KELSEN, 2013, p. 298) para defender a jurisdição constitucional. Contra o argumento de Schmitt de que a atividade controle de constitucionalidade não é uma atividade jurisdicional, mas sim política, Kelsen (2013, p. 251) afirma que o exercício de poder não se encerra no processo legislativo; "encontramos em toda sentença judiciária, em maior ou menor grau, um elemento decisório, um elemento de exercício de poder". Assim, tanto a legislação quanto a jurisdição seriam funções "políticas". Um tribunal constitucional seria um órgão político mais adequado do que o Executivo para exercer o controle de constitucionalidade porque, se o objetivo de um guardião da constituição é garantir que os limites constitucionais ao exercício do poder não sejam ultrapassados, "é indubitável que nenhuma instância é tão pouco idônea para tal função quanto justamente aquela a quem a Constituição confia [...] o exercício do poder e que portanto possui, primordialmente, a oportunidade jurídica e o estímulo político para vulnerá-la" (KELSEN, 2013, p. 240).

${ }^{57}$ Nesse sentido, manifestou-se o Ministro Celso de Mello, no julgamento do AgRg no RE no249.363, aduzindo que cabe à Corte "o monopólio da última palavra". O Ministro Celso de Mello, bem como outros Ministros, tem por hábito citar em seu voto uma passagem de Rui Barbosa: "Em todas as organizações políticas ou judiciais sempre há uma autoridade extrema para errar em último lugar... O Supremo Tribunal Federal, não sendo infalível, pode errar, mas a alguém deve ficar o direito de errar por último, de decidir por último, de dizer alguma cousa que deva ser considerada como erro ou como verdade. Isto é humano".
} 
Ademais, fazendo coro ao que leciona Waldron, os parlamentos, e não as cortes, estão melhores equipados para a discussão das grandes questões políticas e morais de uma sociedade. As razões apontadas por Waldron (2016, pp. 125-144) podem sintetizadas da seguinte forma:

1) as legislaturas são corpos políticos eleitos e responsáveis, sendo que seus membros podem ser regularmente substituídos se desagradarem os seus eleitores;

2) os parlamentos são instituições transparentes ${ }^{58}$, "publicamente dedicados a fazer e modificar a lei";

3) por terem muito mais componentes que os demais ramos do governo, as legislaturas apresentam uma diversidade maior de opiniões, experiências e também de interesses;

4) os parlamentos são instituições representativas, de modo que as opiniões, experiências

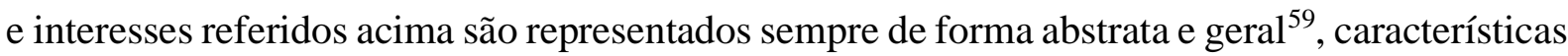
essenciais para a legislação.

Essas características tornam o Poder Legislativo o órgão mais adequado para a elaboração de leis. Assim, a tramitação, discussão e deliberação de projetos de leis são permeadas de regras procedimentais que procuram assegurar racionalidade às decisões públicas, mas, especialmente, garantir a igualdade de tratamento de todos os participantes interessados.

O desentendimento sobre questões de direito é razoável. Nessas circunstâncias, é preciso adotar um procedimento para resolver os desacordos e respeitar as vozes e opiniões de todos os envolvidos, tratando-os com iguais. O Legislativo pode fazer isso. A interferência do Judiciário, além de pouco acrescentar, é uma "forma bastante insultuosa de cerceamento e uma ofuscação

\footnotetext{
${ }^{58}$ Obviamente, alguém poderia querer repristinar a crítica de Schmitt (1996, pp. 20-1) à democracia parlamentar, alegando que "a atividade em si do parlamentar não se realiza durante as conversações no plenário, mas sim em comissões, não necessariamente em comissões parlamentares; as decisões importantes são tomadas em reuniões secretas de dirigentes de facções ou até nos comitês extraparlamentares, dando margem a desvios e isenções de responsabilidades". Waldron (2016, p. 128), entretanto, pondera que "todo tipo de negócio legislativo é feito nos bastidores [...]. Até onde eu sei, o mesmo é verdade para as cortes. Mas, pelo menos, no caso das legislaturas, nós sabemos do que tratam esses acordos: eles são sobre a elaboração de leis. Nas cortes, também existem acordos de bastidores, mas o público acredita - de forma as vezes enganosa - que eles tratam da aplicação, e não da elaboração ou modificação da lei".

${ }^{59}$ Segundo Urbinati (2006, pp. 224-5), a "representação ativa um tipo de unificação política que não pode ser definido em termos de um acordo contratual entre eleitores e eleitos nem resolvido em um sistema de competição para apontar a quem cabe se pronunciar sobre o interesse geral de todos. Um representante político é único não porque ele substitui o soberano na aprovação das leis, mas precisamente porque ele não é um substituto de um soberano ausente (a parte substituindo o todo), uma vez que ele precisa ser constantemente recriado e dinamicamente em sintonia com a sociedade de modo a aprovar leis legítimas".
} 
legalista das questões morais em jogo em nossas discordâncias sobre direitos" (WALDRON, 2016, p. 244).

Deste modo, sustar o debate parlamentar, permitindo o controle judicial preventivo material, mesmo que em casos excepcionais (projetos de leis que violam cláusulas pétreas, por exemplo), implica reduz a autonomia e responsabilidade política e moral do Legislativo e, por consequência, aquilo que Waldron (1999, p. 232) denomina o "direito dos direitos": a participação democrática.

\section{CONCLUSÃO}

O controle preventivo de constitucionalidade é um mecanismo extraordinário de intervenção do Judiciário no processo legislativo, que alegadamente visa proteger o núcleo essencial da Constituição (cláusulas pétreas) contra a ação de maiorias ocasionais. Criado pela jurisprudência do Supremo Tribunal Federal em tempos de déficit democrático, ele poderia ser um importante instrumento para a agenda política da oposição parlamentar, mas foi sempre usado com parcimônia pelo Tribunal.

Com a promulgação da Constituição de 1988, entretanto, o Poder Judiciário e, em especial, o Supremo Tribunal Federal, passam a ocupar um lugar central na configuração do poder estatal. Uma série de pautas que anteriormente eram vistas como campo exclusivo dos poderes Legislativo e Executivo começam a ser debatidas no âmbito do Poder Judiciário, naquele fenômeno conhecido como "judicialização da política".

Somando-se à judicialização, verificou-se também uma mudança da postura dos próprios integrantes do Poder Judiciário, que paulatinamente foram abandonando uma postura autorrestrita por um ativismo cada vez maior na tomada de decisões. Estimulados pelo discurso neoconstitucionalista, os magistrados optam cada vez mais em substituir as razões jurídicas por um sentimento de justiça constitucional, proveniente de princípios abstratos.

Essas mudanças são especialmente relevantes quando se admite a intervenção judicial ainda no decorrer do processo legislativo. Isso porque torna possível que os magistrados interrompam o debate político e o substituam por suas próprias convicções ou agendas pessoais, o que indubitavelmente afronta o princípio democrático. Mas mesmo que eles ajam de forma 
imparcial, não há como se inferir que suas razões sejam superiores às das demais autoridades políticas eleitas.

Os parlamentos, por outro lado, são estruturados de forma que todas as opiniões possam ser levadas igualmente em consideração. É justamente essa estrutura plural, onde cada voto conta com peso igual, que outorga à lei sua legitimidade democrática. Suas deliberações, portanto, devem ser respeitadas. Trata-se de uma homenagem a ação concentrada dos indivíduos, mesmo diante do fato inexorável do desacordo.

\section{REFERÊNCIAS}

ARENDT, Hannah. A condição humana. Tradução de Roberto Raposo. 10. ed. Rio de Janeiro: Forense, 2001.

ARENDT, Hannah. Entre o passado e o futuro. Tradução de Mauro W. Barbosa de Almeida; apresentação de Celso Lafer. 5. ed. São Paulo: Editora Perspectiva, 2002.

BARROSO, Luís Roberto. Contramajoritário, representativo e iluminista: os papéis dos tribunais constitucionais nas democracias contemporâneas. In Revista Direito e Práxis, Rio de Janeiro, v. 9, n. 4, 2018, pp. 2171-2228.

BARROSO, Luís Roberto. O controle de constitucionalidade no direito brasileiro. 4. ed. São Paulo: Saraiva, 2009.

BRANDÃO, Rodrigo. Supremacia judicial versus diálogos constitucionais: a quem cabe a última palavra sobre o sentido da constituição? Rio de Janeiro: Lumen Juris, 2012.

CAMPOS, Carlos Alexandre de Azevedo. Dimensões do ativismo judicial no Supremo Tribunal Federal. Rio de Janeiro: Forense, 2014.

CAMPOS, Francisco. Direito constitucional. 1. Ed. Rio de Janeiro: Freitas Bastos, 1956 (vol.2).

COSTA, Alexandre Araújo; COSTA, Henrique Araújo. Evolução do perfil dos demandantes no controle concentrado de constitucionalidade realizado pelo STF por meio de ADIs e ADPFs. In Revista de ciências sociais, v. 49, n. 2, jul/out, 2018, pp 133-79.

DWORKIN, Ronald. O direito da liberdade: a leitura moral da Constituição norte-americana. Tradução de Marcelo Brandão Cipolla. São Paulo: Martins Fontes, 2006.

DWORKIN, Ronald. O domínio da vida. Tradução de Jefferson Luiz Camargo. São Paulo: Martins Fontes, 2003. 
DWORKIN, Ronald. O império do direito. Tradução de Jefferson Luiz Camargo. São Paulo: Martins Fontes, 1999.

DWORKIN, Ronald. A justiça de toga. Tradução de Jefferson Luiz Camargo. São Paulo: Editora WMF Martins Fontes, 2010a.

DWORKIN, Ronald. Levando os direitos a sério. Tradução de Nelson Boeira. 3. ed. São Paulo: Editora WMF Martins Fontes, 2010.

DWORKIN, Ronald. A virtude soberana: teoria e prática da igualdade. Tradução de Jussara Simões. São Paulo: Martins Fontes, 2005a.

DWORKIN, Ronald. Uma questão de princípios. Tradução de Luís Carlos Borges. 2. ed. São Paulo: Martins Fontes, 2005.

FERREIRA FILHO, Manoel Gonçalves. Do Processo Legislativo. São Paulo: Saraiva, 2012.

FEREJOHN, John. Judicializando a política, politizando o direito. In MOREIRA, Luiz (org.). Judicialização da política. São Paulo: 22 Editorial, 2012.

GARAPON, Antonie. O guardador de promessas: justiça e democracia. Tradução de Francisco Aragão. Lisboa: Instituto Piaget, 1998.

HIRSCHL, Ran. A judicialização da megapolítica e o surgimento dos tribunais políticos. In MOREIRA, Luiz (org.). Judicialização da política. São Paulo: 22 Editorial, 2012, pp. 2762.

KELSEN, Hans. Jurisdição constitucional. Tradução de Alexandre Krug et al. 3. ed. São Paulo: WMF Martins Fontes, 2013.

LIMONGI, Fernando. Em defesa do Congresso. Valor Econômico, São Paulo, p. 8-A, 30 abr. 2013.

MAUS, Ingeborg. O judiciário como superego da sociedade: o papel da atividade jurisprudencial na "sociedade órfã". Tradução de Martonio Lima e Paulo Albuquerque. In Novos Estudos CEBRAP, n 58, 2000, pp. 103-202.

MELLO, Cláudio Ari. Kant e a dignidade da legislação. Porto Alegre: Livraria do Advogado Editora, 2010.

MENDES, Conrado Hübner. Controle de constitucionalidade e democracia. Rio de Janeiro: Elsevier, 2008.

MENDES, Conrado Hübner. Direitos fundamentais, separação de poderes e deliberação. São Paulo: Saraiva, 2011. 
MENDES, Gilmar Ferreira; BRANCO, Paulo Gustavo Gonet; COELHO, Inocêncio Mártires. Curso de direito constitucional. 5. ed. São Paulo: Saraiva, 2010.

OLIVEIRA, Cláudio Ladeira. Ativismo judicial, autorestrição judicial e o minimalismo de Cass Sunstein. In Diritto \& Diritti, v. 1, p. 1-21, 2008.

OLIVEIRA, Cláudio Ladeira. Democracia e ativismo judicial: algumas considerações sobre suas causas e consequências. In Revista de direitos e garantias fundamentais, Vitória, v. 16, n. 1, jan./jun. 2015, pp. 183-216.

OLIVEIRA, Marcelo Andrade Cattoni de. Devido processo legislativo: uma justificação democrática do controle jurisdicional de constitucionalidade das leis e do processo legislativo. 3. ed. Belo Horizonte: Fórum, 2016.

PEREIRA, Bruno Cláudio Penna Amorim. Jurisdição constitucional do processo legislativo: legitimidade, reinterpretação e remodelagem do sistema no Brasil. Belo Horizonte: Fórum, 2012.

RAWLS, John. O liberalismo político. Tradução de Dinah de Abreu Azevedo. São Paulo: Editora Ática, 2000.

RODRIGUEZ, José Rodrigo. Como decidem as cortes? Para uma crítica do direito (brasileiro). Rio de Janeiro: Editora FGV, 2013.

SCHMITT, Carl. A crise da democracia parlamentar. Tradução de Inês Lohbauer. São Paulo: Scritta, 1996.

SCHMITT, Carl. La defensa de la constitución. Tradução de Manuel Sanchez Sarto. 2. ed. Madrid: Tecnos, 1998.

SILVA, Virgílio Afonso da. A emenda e o Supremo. Valor Econômico, São Paulo, p. 18-A, 03 mai. 2013.

STRECK, Lenio Luiz. Jurisdição constitucional e hermenêutica: uma nova crítica do direito. Porto Alegre: Livraria do Advogado, 2011.

TAYLOR, Matthew M.; ROS, Luciano Da. Os partidos dentro e fora do poder: a judicialização como resultado contingente da estratégia política. In DADOS -Revista de Ciências Sociais, Rio de Janeiro, v. 51, n. 4, 2008, p. 825-64.

TORRANO, Bruno. Democracia e respeito à lei: entre positivismo jurídico e pós-positivismo. Rio de Janeiro: Lumen Juris, 2015. 
URBINATI, Nadia. Representative democracy: principles \& genealogy. Chicago: The University of Chicago Press, 2006.

VERÍSSIMO, Marcus Paulo. A Constituição de 1988, vinte anos depois: suprema corte e ativismo judicial "à brasileira”. In Revista direito GV. São Paulo, vol. 4, n. 2, jul./dez. 2008, pp. 407-440.

VIANNA, Luiz Werneck et al. A judicialização da política e das relações sociais no Brasil. Rio de Janeiro: Revan, 1999.

VIEIRA, Oscar Vilhena. Supremocracia. In Revista direito GV. São Paulo, vol. 4, n. 2, jul./dez. 2008, pp.441-463.

WALDRON, Jeremy. Control de constitucionalidad y legitimidad política. In Dikaion, 27, 1, pp. 7-28, 2018.

WALDRON, Jeremy. A dignidade da legislação. Tradução de Luís Carlos Borges. São Paulo: Martins Fontes, 2003.

WALDRON, Jeremy. Law and disagreement. Oxford: Oxford University Press, 1999.

WALDRON, Jeremy. Normative (or ethical) positivism. In COLEMAN, Jules (org.). Hart's postscript: essays on the postscript to The concept of law. Oxford: Oxford University Press, 2001, pp. 410-33.

WALDRON, Jeremy. Political political theory: essays on institutions. Cambridge: Harvard University Press, 2016.

WALDRON, Jeremy. A right-based critique of constitutional rights. In Oxford Journal of Legal Studies, v. 13, 1993.

Data da submissão:10/04/2020

Data da primeira avaliação:23/07/2020

Data da segunda avaliação: 06/08/2020

Data da aprovação: 06/08/2020 